\title{
Sciendo
}

\section{Factors influencing the job search and job selection in students of Generation Y in the Czech Republic in the employer branding context}

\author{
Jiří BEJTKOVSKÝ \\ Tomas Bata University in Zlín, Zlín, Czech Republic \\ bejtkovsky@utb.cz
}

\begin{abstract}
The factors influencing job search and job selection are related to employer branding, employer's position and employer attractiveness on labour market. These factors make employer branding. A conception of employer branding is hot issue not only in scientific research area. The employer branding can be divided into internal and external branding. The main goal of this article was to discover the factors influencing the job search and job selection based on the gender of the respondents and the type of faculty in the employer branding context. The students of Generation Y introduced a research sample of respondents. The primary data was acquired by structured questionnaire targeted at selected students of Generation $Y$ in the Czech Republic. The total number of respondents was 655 students. Two research hypotheses and one research question have been defined. An analysis was realized using statistical software IBM Statistical Package for Social Science (SPSS) Statistics 23 and Microsoft Excel 2013. . The verification of the research hypotheses was performed by the statistical method of the Two-sample t-Test for equal means. The research results discovered the findings that the mean perceptions of the factors influencing the job search and job selection: (1) were as the same for females and males, (2) were as the same for Generation Y students of the Faculty of Humanities (FHS) and Faculty of Management and Economics (FaME). Information about potential employers in the employer branding context was also investigated. The most frequent information about potential employers was information about job position and working conditions.
\end{abstract}

Keywords: Czech Republic, employer branding, generation Y, internal and external branding, marketing, students, the Two-sample t-Test for equal means.

Please cite the article as follows: Bejtkovský, J., (2018), "Factors influencing the job search and job selection in students of Generation $\mathrm{Y}$ in the Czech Republic in the employer branding context", Management \& Marketing. Challenges for the Knowledge Society, Vol. 13, No. 3, pp. 1133-1149, DOI: 10.2478/mmcks-2018-0028.

\section{Introduction}

A lack of qualified human resources and permanent battle for suitable staff, together with preserving of human resources belong to the most important manpower questions and problems for the corporations in today's business environment. HR marketing and employer branding can bring new opportunities and changes in these fields (Urbancová and Hudáková, 2017).

According to Keller (2013), a brand is not built by randomness but it is a result of meaningfully and systematically implementation, either implicitly or explicitly, a series of consistently and rationally linked activities with buyers, customers, consumers or clients.

In context of human resource management, personnel marketing and brand marketing, employer branding has been named as an efficient corporate strategy 
to distinguish from competing companies in the industry and increase a competitive advantage in the labour market (Collins and Stevens, 2002; Lievens, 2007).

The concept of employer branding, a connection of marketing and human resource management, emerged and gained ground during the 90s (Shaikh Ibrahim, 2016).

Regarding this, Brymer, Molloy and Gilbert (2014) present an idea that the recruitment process of human resources is of indisputable importance for corporations, since employees have the possible to be a dominant and key element of competitive advantage.

As corporate environment contend many issues employer branding became a significant part of long-term corporate strategy. It is assumed that corporations will try managing the perceptions and awareness of existing and new human resources. (Stuss and Herdan, 2017).

Regarding this, Martindale (2010) mentions that employer branding and HR marketing are seen as an important and interesting conception for responding to recruitment and retention challenges in today's corporations.

According to App, Merk and Büttgen (2012), procedures, processes and approaches in human resource area, in terms of career and development, stimulation, motivation or remuneration, for instance, contribute to the creation of a special importance proposition communicated by employer brand.The employer branding symbolizes a corporation's interests to promote, both within and outside the corporation, an evident opinion of what makes it various, suitable and necessary and as an employer. Employer branding concept has achieved fame for success in recent years even nowadays (Backhaus and Tikoo, 2004).

As Peretti and Swalhi (2007) note, skilled human resources have become aware of the considerable chances on the job market and the opportunities of guiding their careers by experience in various corporations.

According to Berthon, Ewing and Hah (2005), there are five elements at play in employer brand development: social factors: friendly work relations, teamwork, motivating and stimulating environment; development factors: confidence, recognition, evolving and enriching career; application factors: possibilities to apply and transfer knowledge; economic factors: possibilities for advancement, security and remuneration; interest factors: newer methods and techniques, support of employees creativity and challenging, interesting and attractive work environment.

Bursová (2009) adds that a process of the employer brand building is essential and significant in the field of job satisfaction and job motivation of the staff and in recruitment and in search for new potential human resources for miscellaneous job vacancies in corporation.

The major aim of this paper is to discover the factors influencing the job search and job selection based on the gender of the respondents and the type of faculty (FHS, FaME). The students of Generation Y constitute a research sample of respondents. The primary data will be acquired by structured questionnaire targeted at selected students of Generation Y in Czech Republic. 


\section{Literature review}

\section{Employer branding and employer attractiveness}

According to Vendolská and Kačerová (2016), a situation and conditions on the labour market, not only in the Czech Republic, show great changes not only for corporations but also for human resources (potential candidates). Regarding this, Deaconu, Marinas and Puia (2008) say that the requirement of job search, job selection and evaluating the human resources in corporation is imposed by the faster tempo of the technicalscientific and economic development, by the emergence of some perform in almost all activity areas, by the fierce competition due to the international extension of many companies' activity.

Demographic facts, data and trends are forcing corporation to revise their positions in the labour market. It is obvious that it is not the multiple the potential employees (candidates) that compete for the same job position in corporation but rather that there are several corporations and positions within them competing for the same potential employee in the labour market. Because of this the role of human resource management is changing, adding to their usual activities also the task of selling the job positions. In doing this it may be beneficial to seek help in areas that were formerly thought as pure marketing department fields. Building on the opinion of the image and reputation of corporations and their brand discovered the concept of a corporation's brand as an employer - employer brand (Franca and Pahor, 2012).

Regarding this, Guthridge, Komm and Lawson (2008) assert that in light of an ever-increasing global shortage of the experienced and qualified people, corporations are seeking effective and diverse approaches to attract and retain potential and current human resources. The process of globalisation has allowed subjects to compete with other subjects from all over the world to attract resources: human, financial, materials and infrastructure (Popescu, 2012). Nevertheless, Porvazník, Ljudvigová and Vydrová (2017) say that the process of globalisation means more dangers than opportunities, which leads to human crisis on a global scale.

Various industries are facing cumulative competitive fight among corporations to inspire loyal, skilled and experienced employees (McDonnell, 2011).

Regarding this, Urbancová, Richter, Kučírková and Jarkovská (2017) say that employer branding process; the bettering public awareness and growing the loyalty and satisfaction of the present human resources can obtain new qualified human resources.

The employer branding describes to a corporation's image and reputation as an employer and its value proposition to its employees (Barrow and Mosley, 2011).

According to Lane (2016), the employer branding contains the principles, practices and tools by which a corporation influences its image, reputation and brand as an employer, among specified segments - for example current and potential employees.

Employer brand provides economical, psychological and functional benefits offered by the corporation (Ambler and Barrow, 1996; Berthon, Ewing and Hah, 2005).

Regarding this, Charbonnier-Voirin, Poujol and Vignolles (2017) say that employer branding is of growing needs to corporations facing employee attractiveness, motivation and retention problems. 
According to Mitra Crişan (2013), nowadays corporations that underestimate social activities will have more and more a handicap in their employer branding and their business.

Employer brand contains the symbolic, nominal and helpful characteristics of the job activity and of the corporation as perceived by human resources (internal employer brand - internal marketing concept) and candidates (external employer brand - external marketing concept). Employer brand is also understood a value proposition and a pledge for current and potential human resources (Franca and Pahor, 2012; Soulez and Guillot-Soulez, 2011; Srivastava and Bhatnagar, 2010).

The internal marketing concept declares that corporation's human resources are its primary marketplace. One element of internal marketing that is still insufficiently developed is employer branding and particularly employer attractiveness. The employer attractiveness is described as the expected advantages that a potential person sees in working for a corporation (Berthon, Ewing and Hah, 2005).

According to Lievens (2007), the employer brand management contains three main levels to interest and retain workforce: (1) characterization the employer's value proposition (the offer tied to corporate goals, values and work characteristics), (2) communicating that offer, and (3) aligning the employer's internal and external brand to ensure that the corporate identity promoted includes reality in the workplace.

External employer brand must be a sufficient and suitable work reflection of human resource and the corporation (Mark and Toelken, 2009).

Employer attractiveness is perceived and evaluated from a holistic point of view, defined by Collins and Kanar (2013) as subjective assessments of the attractiveness of a brand described through surface brand associations.

Regarding this, Kissel and Büttgen (2015) impart that the employer attractiveness mainly depends on a comprehensive assessment of a corporation according to its corporate image; it is not a rapid procedure determined by specific job-related information acquired in social media platforms.Xie, Bagozzi and Meland (2015) state that corporation's reputation, employer attractiveness and corporation's reputation between applicants' self-identities (applicants not only the Generation Y) and their perceived corporation identity influence on job applicants' job pursuit intentions through mediation of cognitive social identity.

\section{Weakness of the employer branding}

A research area of the employer branding has got several imperfections and weaknesses. First, there are frequently differences in the debates about the employer brand, especially the identifier, process, and the development of employer branding (Davies, 2008; Moroko and Uncles, 2008). Second, various related approaches, concepts and terms such as internal and employee branding, employer name and image and employment image or employer brand equity and employer knowledge are dissimilarly described and implemented (Edwards and Edwards, 2013; King and Grace, 2008; Lievens and Slaughter, 2016; Saleem and Iglesias, 2016). Third, the employer branding research has been carried out in various other areas (for example marketing) and in related research areas (e.g. the corporation attractiveness), making it hard to distinguish those researches from actual employer branding papers 
(Berthon, Ewing and Hah, 2005; Chapman, Uggerslev, Carroll, Piasentin and Jones, 2005). Fourth, there is no universal conformity with the target segment of employer branding. Although most scientific papers, researches or projects describe a focus on potential and current human resources, the majority of empirical research focuses on only recruitment of employees (Lane, 2016).

\section{The Generation $Y$}

According to Racolța-Paina and Luca (2011), nowadays' turbulent era spins around the interesting challenges brought along by the informational society. Therefore, the Internet provided the perspectives on digital world of networking, information, and lack of space and time obstacles. Also, it triggered the form of a New Economy, new population - the Generation $Y$ and a new employee and costumer.

The Generation Y is often named as Millennials, as the first global generation or as Next Generation or as Google or @ Generation. The people of Generation Y have akin typical features, attributes and characteristics, regardless of their birth (their country of origin). The people from Generation Y were born between 1980 and 1995 (Horváthová, Bláha and Čopíková, 2016; Knight, 2014; Zemke, Raines and Filipczak, 2000).

Noble, Haytko and Phillips (2009) say that the Generation Y includes people born between years 1977 and 2000. Other research workers or authors shorten this period to years 1980 - 1994 (for example, Bednall, Valos, Adam and McLeod, 2012).

The Generation Y (e.g., Cogin, 2012; Shaw and Fairhurst, 2008; Shen Kian, Wan Yusoff and Rajah, 2013; Wan Yusoff and Shen Kian, 2013): are energetic and positive; give preference to sincerity and openness; want flexibility; job is just one preference in life - not the preference; want a positive work environment; want training and development; expect to be empowered; want negligible rules; require daily feedback; are online 24 hours a day.

People of Generation Y comprehend that the using of online tools can bring them the interesting advantages. People of Generation Y use social media networks very often to communicate and are truly interested in new technologies in the market (Klapilová Krbová, 2016).

Regarding this, Curus (2008) informs that statistics demonstration that in general, any 21 years old youngster has already sent an impressive number of 250,000 e-mails and text messages, also spending 3,500 hours socializing online.

In this article, the Generation Y consists of people born between 1980 and 2000.

\section{Methodology}

The contribution deals with the employer branding. The employer branding and employer attractiveness were evaluated by students of Generation Y in the Czech Republic. It is important to realize that the employer branding is built through HR marketing (personnel marketing) tools. A research sample of respondents was constituted by students at Tomas Bata University in Zlín.

The main goal of the submitted paper was to discover the factors influencing the job search and job selection based on the gender of the respondents and the type 
of faculty. A quantitative research was realized at TBU in Zlín. The respondents were students of these faculties and were representatives of Generation Y.

Professional scientific monographs, scientific journals and scientific papers in the Web of Science database and Scopus database dealing with the contemporary questions and issues, namely employer branding, employer attractiveness and the Generation Y, were analysed within the secondary sources.

Primary data were achieved by qualitative and quantitative marketing research. Some of the results are introduced in this contribution.

The research sample of respondents was selected randomly. The condition was that both the female and the male must have been Generation Y students of FHS and FaME.

The qualitative marketing research was carried out through semi-standardized interviews with selected students of Generation Y (the students of FHS and FaME) in 2017 (in October). A main aim of this exploratory research was explained the research goal and suggested an anonymous questionnaire survey.

The quantitative marketing research was implemented through questionnaire survey. The structured questionnaires were available in the electronic (via email) as well as printed form and distributed among selected students of Generation Y.

Open questions, semi-open questions and closed questions, which were assembled on the basis of the study of professional scientific monographs, documents and semi-standardized interviews, were used to obtain answers. The questionnaire survey respected anonymity of respondents and ethical aspect.

A pretest of the structured questionnaire survey was realized in November 2017. The pretest of the structured questionnaire survey was performed on a sample of twenty respondents. A comprehensive questionnaire survey was performed on the basis of an evaluation of the pretest results. This research was conducted from December 2017 to January 2018.

A total number of 655 relevant questionnaires were acquired. In order to assess the research results, descriptive statistics tools such as absolute and relative frequencies were used.

Two research hypotheses (H1, H2) and one research question (RQ1) were defined on the basis of exploratory research, especially literary research, analysis and evaluation of the information and facts obtained:

$\mathrm{H} 1_{0}$ : According to the respondents participating in the research sample, the mean perception of the factors influencing the job search and job selection females and males is equal.

$\mathrm{H} 1_{0}: \mu 1-\mu 2=0$

$\mathrm{H} 1_{\mathrm{A}}$ : According to the respondents participating in the research sample, the mean perception of the factors influencing the job search and job selection females and males is different.

$\mathrm{H} 1_{\mathrm{A}}: \mu 1-\mu 2 \neq 0$

$\mathrm{H} 2_{0}$ : According to the respondents participating in the research sample, there is no difference in the mean perception of the factors influencing the job search and job selection between Generation Y students of the FHS and FaME.

$$
\mathrm{H} 2_{0}: \mu 3-\mu 4=0
$$


$\mathrm{H} 2_{\mathrm{A}}$ : According to the respondents participating in the research sample, there is difference in the mean perception of the factors influencing the job search and job selection between Generation Y students of the FHS and FaME.

$\mathrm{H} 2_{\mathrm{A}}: \mu 3-\mu 4 \neq 0$

$\mathrm{RQ1}$ : What type of looking for information about potential employers will be the most frequent according to addressed students of Generation Y?

The verification of the proposed research hypotheses was performed by the Two-sample t-Test for equal means. A formula for the pooled estimator of $\sigma^{2}$ is:

$$
S_{p}^{2}=\frac{\left(n_{1}-1\right) s_{1}^{2}+\left(n_{2}-1\right) s_{2}^{2}}{n_{1}+n_{2}-2}
$$

Where $s_{1}$ and $s_{2}$ are the standard deviations of the two samples of respondents (women and men, FHS and FaME) and $n_{1}$ and $n_{2}$ are the sizes of the two samples of respondents.

The formula for comparing the means of two populations using pooled variance is:

$$
t=\frac{\overline{x_{1}}-\overline{x_{2}}-\Delta}{\sqrt{\sqrt{x_{p}^{2}}\left(\frac{1}{n_{1}}+\frac{1}{n_{2}}\right)}}
$$

Where equation and equation are the means of the two samples, $\Delta$ is the hypothesized difference between the two samples of respondents ( 0 if testing for equal means), $\mathrm{sp}^{2}$ is the pooled variance, and $\mathrm{n}_{1}$ and $\mathrm{n}_{2}$ are the sizes of the two samples. The number of degrees of freedom for the problem is:

$$
d f=n_{1}+n_{2}-2
$$

To evaluate the data, a statistical software IBM SPSS Statistics 23 and Microsoft Excel 2013 were used. The results of qualitative and quantitative marketing research were used for answering the formulated research question. The selected scientific methods, including analysis, synthesis, induction and deduction, were used for processing of both secondary and primary information resources and to define the research conclusions.

\section{The specification of the sample of respondents}

The qualitative marketing research, the semi-standardized interviews, was comprised of twenty-five respondents - students of Generation Y (the students of the FHS and FaME). The quantitative marketing research, an anonymous questionnaire survey, was composed of 655 respondents. Thirteen questionnaires were excluded because of incomplete information.

The respondents were segmented according to the following criteria: gender of respondents, biological age of the respondents and faculty of respondents.

In this article, the Generation Y consists of people born between 1980 and 2000. The structure of the addressed students of Generation $Y$ is shown in the table below (Tab. 1).

Table 1. The structure of the addressed students of Generation $Y$

\begin{tabular}{|c|c|r|r|}
\hline \multirow{2}{*}{ Variable } & Category & \multicolumn{1}{|c|}{$\begin{array}{c}\text { The absolute } \\
\text { frequency (N) }\end{array}$} & \multicolumn{1}{c|}{$\begin{array}{c}\text { The relative } \\
\text { frequency (\%) }\end{array}$} \\
\hline \multirow{2}{*}{ Gender } & Female & 389 & 59.39 \\
\cline { 2 - 4 } & Male & 266 & 40.61 \\
\hline
\end{tabular}

Vol. 13, No. 3, Autumn, pp. 1133-1149, ISSN 1842-0206 | Management \& Marketing. Challenges for the Knowledge Society 


\begin{tabular}{|c|c|c|c|}
\hline & Total & 655 & 100.00 \\
\hline \multirow{7}{*}{$\begin{array}{c}\text { Biological } \\
\text { age }\end{array}$} & 19 years & 42 & 6.42 \\
\hline & 20 years & 138 & 21.07 \\
\hline & 21 years & 156 & 23.82 \\
\hline & 22 years & 144 & 21.98 \\
\hline & 23 years & 96 & 14.66 \\
\hline & 24 years and over & 79 & 12.05 \\
\hline & Total & 655 & 100.00 \\
\hline \multirow{3}{*}{ Faculty } & FHS & 286 & 43.67 \\
\hline & FaME & 369 & 56.33 \\
\hline & Total & 655 & 100.00 \\
\hline
\end{tabular}

Source: Author's own results.

The table (Tab. 1) describes the structure of the addressed students of Generation Y. The variables are: gender, biological age and faculty of respondents.

\section{Empirical results}

This chapter describes the main results of research. The main aim of this research was to discover the factors influencing the job search and job selection based on the gender of the respondents and the type of faculty. The students of Generation Y introduced a research sample of respondents (the Generation Y consists of people born between 1980 and 2000).

The factors influencing the job search and job selection were determined as follows: (A) certainty of employment, (B) permanent salary/wages, (C) good relationships in the workplace, (D) good career development possibilities, (E) employee benefits (telephone allowance, car, meals, travel, housing, etc.), (F) successful and well-known corporation on the market, (G) environmentally orientated production of corporation, $(\mathrm{H})$ flextime - flexible working hours, (I) work with modern equipment and technologies, (J) existence of corporate rules, $(\mathrm{K})$ other employee benefits, (L) space for own realization.

The respondents used the 5-point Likert-type scale (from $1=$ strongly importance to $5=$ strongly irrelevance) to respond to the scale items in this measure.

\section{Difference between female and male respondents}

The research sample of respondents for the first part of research - explored the difference in perception of the factors influencing the job search and job selection between women and men. The research sample comprised of 389 women and 266 men.

As mentioned above, the determination of differences in perception of women and men was made by the Two-sample t-Test for equal means. The results of the Twosample t-Test for equal means are shown in the table below (Tab. 2).

Table 2. Test of hypothesis H1 - the Two-sample t-Test for equal means

\begin{tabular}{|c|c|c|c|c|c|c|}
\hline Factors & $\mathbf{t}$ & $\mathbf{d f}$ & p-value & $\begin{array}{c}\text { Mean } \\
\text { Difference }\end{array}$ & $\begin{array}{c}\text { Std. Error } \\
\text { Difference }\end{array}$ & $\begin{array}{c}\text { 95\% Confidence } \\
\text { Interval of the Diff. }\end{array}$ \\
\hline
\end{tabular}

Vol. 13, No. 3, Autumn, pp. 1133-1149, ISSN 1842-0206 | Management \& Marketing. Challenges for the Knowledge Society 


\begin{tabular}{|c|c|c|c|c|c|c|c|}
\hline & & & & & & Lower & Upper \\
\hline $\mathbf{A}$ & -1.556 & 653 & .120 & -.148 & .095 & -.335 & .039 \\
\hline $\mathbf{B}$ & -.773 & 653 & .440 & -.052 & .067 & -.183 & .080 \\
\hline $\mathbf{C}$ & -.113 & 653 & .910 & -.006 & .053 & -.111 & .099 \\
\hline $\mathbf{D}$ & -.723 & 653 & .470 & -.032 & .044 & -.119 & .055 \\
\hline $\mathbf{E}$ & -.064 & 653 & .949 & -.004 & .057 & -.115 & .108 \\
\hline $\mathbf{F}$ & -.232 & 653 & .816 & -.019 & .080 & -.175 & .138 \\
\hline $\mathbf{G}$ & 1.234 & 653 & .218 & .085 & .069 & -.050 & .221 \\
\hline $\mathbf{H}$ & 1.089 & 653 & .277 & .052 & .047 & -.041 & .144 \\
\hline $\mathbf{I}$ & .390 & 653 & .697 & .030 & .077 & -.122 & .182 \\
\hline $\mathbf{J}$ & .760 & 653 & .448 & .033 & .043 & -.052 & .117 \\
\hline $\mathbf{K}$ & 3.754 & 653 & .000 & .302 & .081 & .144 & .460 \\
\hline $\mathbf{L}$ & 1.314 & 653 & .189 & .095 & .072 & -.047 & .236 \\
\hline
\end{tabular}

Source: Author's own results.

The two-Sample t-Test for equal means showed the following results. Since the pvalues are greater than the significance level (0.05), for all factors, except other employee benefits, the null hypothesis cannot be rejected.

According to respondents participating in the research sample, it can be confirmed the mean perception of the factors influencing the job search and job selection for females and males is as the same. It differs for one factor only other employee benefits. It means that this one factor shows differences in perception between women and men.

\section{Difference between Generation Y students of the FHS and FaME}

The research sample of respondents for the second part of research - explored the difference in perception of the factors influencing the job search and job selection between Generation Y students of the FHS and FaME. The research sample consisted of 286 students of the FHS and 369 students of the FaME.

As mentioned above, the determination of differences in perception of students of the FHS and FaME was made by the Two-sample t-Test for equal means. The results of the Two-sample t-Test for equal means are shown in the table below (Tab. 3).

Table 3. Test of hypothesis H2 - the Two-sample t-Test for equal means

\begin{tabular}{|c|c|c|c|c|c|c|c|}
\hline \multirow[t]{2}{*}{ Factors } & \multirow[t]{2}{*}{$t$} & \multirow[t]{2}{*}{ df } & \multirow[t]{2}{*}{ p-value } & \multirow{2}{*}{$\begin{array}{c}\text { Mean } \\
\text { Difference }\end{array}$} & \multirow{2}{*}{$\begin{array}{l}\text { Std. Error } \\
\text { Difference }\end{array}$} & \multicolumn{2}{|c|}{$\begin{array}{l}95 \% \text { Confidence } \\
\text { Interval of the Diff. }\end{array}$} \\
\hline & & & & & & Lower & Upper \\
\hline A & 2.543 & 653 & .011 & .239 & .094 & .055 & .424 \\
\hline B & 2.539 & 653 & .011 & .167 & .066 & .038 & .296 \\
\hline C & 2.804 & 653 & .005 & .147 & .053 & .044 & .250 \\
\hline D & -.245 & 653 & .807 & -.011 & .044 & -.097 & .075 \\
\hline E & 1.374 & 653 & .170 & .077 & .056 & -.033 & .187 \\
\hline $\mathbf{F}$ & -.744 & 653 & .457 & -.059 & .079 & -.213 & .096 \\
\hline G & .454 & 653 & .650 & .031 & .069 & -.104 & .166 \\
\hline H & 1.211 & 653 & .226 & .057 & .047 & -.035 & .149 \\
\hline I & -.620 & 653 & .536 & -.048 & .077 & -.198 & .103 \\
\hline $\mathbf{J}$ & 2.075 & 653 & .038 & .088 & .042 & .005 & .171 \\
\hline $\mathbf{K}$ & 1.807 & 653 & .071 & .145 & .080 & -.013 & .303 \\
\hline $\mathbf{L}$ & 2.214 & 653 & .027 & .157 & .071 & .018 & .297 \\
\hline
\end{tabular}

Source: Author's own results. 
The two-Sample t-Test for equal means showed the results from the table above. Since the p-values are greater than the significance level $(0.05)$, except for factors: $A, B, C, J$ and $\mathrm{L}$, the null hypothesis cannot be rejected.

According to respondents participating in the research sample, it can be confirmed the mean perception of the factors influencing the job search and job selection for Generation Y students of the FHS and FaME is as the same. It differs for five factors only $\mathrm{A}, \mathrm{B}, \mathrm{C}$, J and $\mathrm{L}$.

It means that these five factors show differences in perception between Generation Y students of the FHS and FaME.

\section{Information about potential employers}

Based on qualitative research, the possible areas of information about potential employer were defined. These possible areas were further explored through quantitative marketing research. The structured questionnaire survey, besides other things, also included a selection question. This selection question examined information about potential employers and its frequency. The respondent had a choice of the following alternatives: general information about corporation (core values, targets, vision, and so on); information about job position and working conditions; references and corporation rating (work atmosphere, career opportunities, and so on); information about internships or trainee programs for students. The respondents could choose more choice alternatives.

The table (Tab. 4) presents information about potential employers according to frequency. The frequency was evaluated by addressed students of Generation Y.

Table 4. Information about potential employers

\begin{tabular}{|c|c|}
\hline Factors & The absolute frequency (N) \\
\hline Information about job position and working conditions & 655 \\
\hline References and corporation rating & 632 \\
\hline General information about corporation & 604 \\
\hline $\begin{array}{c}\text { Information about internships or trainee programs for } \\
\text { students }\end{array}$ & 588 \\
\hline
\end{tabular}

Source: Author's own results.

As it can be seen from the table (Tab. 4) above, the most frequent information about potential employers was information about job position and working conditions. References and corporation rating (work atmosphere, career opportunities, and so on) were on the second place. General information about corporation (core values, targets, vision, and so on) was on the third place. Information about internships or trainee programs for students was finished on the fourth place.

\section{Discussion}

Moroko and Uncles (2008) introduce idea that as with customer-centric brands, attractiveness is based on attentiveness, differentiation and significance.

The main goal of this paper was to determine the factors influencing the job search and job selection based on the gender of the respondents and the type of faculty. The students of Generation Y introduced a research sample of respondents. 
The results came along with the finding that the mean perception of the factors influencing the job search and job selection for females and males was as the same. This mean perception differed for one factor only other employee benefits. It means that this one factor showed differences in perception between women and men. And also, the mean perception of the factors influencing the job search and job selection for Generation Y students of the FHS and FaME was as the same. This mean perception differed for five factors only: (1) certainty of employment, (2) permanent salary/wages, (3) good relationships in the workplace, (4) existence of corporate rules, (5) space for own realization. It means that these five factors showed differences in perception between Generation Y students of the FHS and FaME. Information about potential employers was also investigated. The most frequent information about potential employers was information about job position and working conditions.

In connection with the survey results it can be stated that for the Slovak students is the most relevant variable by choosing an employer permanent employment and permanent salary ( $90 \%$ of respondents). It should be highlighted that the variable of permanent employment and steady salary are momentous only for $41 \%$ of Chinese students, which is less than half compared to the result in Slovak Republic. For students in China is the most significant variable the opportunity for career development (78 \% of respondents). Friendly working atmosphere and positive relationships in the workplace are important for Chinese and Slovak students. People of the Generation Y perceive that the time spent at work considerably affects the quality of their personal lives, and therefore they gave this variable a great significant $72 \%$ of respondents from China and $77 \%$ of respondents from Slovak Republic). Only about for $33 \%$ of the students from China and Slovakia are important activities in the environmental area and the quality of its production (Plchová and Turáková, 2016).

According to Reis and Braga (2016) and their research survey, remunerations, development possibilities, and social relationships and needs are characteristics that could be highlighted in the job offer focused on employees of the Generation Y.

Dabirian, Kietzmann and Diba (2017) identified by their research study seven key employer branding areas that current, former, and potential human resources care about when they assess corporations. These findings introduce: (1) social factors of job, (2) challenging, motivating and interesting job tasks, (3) the dimension to which knowledge and skills can be used in significant ways, (4) chances for personal and professional development, (5) compensation for employees, (6) the importance of management, and (7) work/life balance. These key areas do not all matter to the same extent and illustrate how their relationships and importance differ across corporations, particularly if corporations are considered particularly successful or unsuccessful places to work.

According to Leekha Chhabra and Sharma (2014) and their researches, it was found that among the students, favourite corporate characteristics were corporate culture, brand name and compensation. Students evaluated job portal to be the favored channel for employer attractiveness. The research showed that there exists an important and positive correlation between likelihood to apply and strong brand image. 
Wołodźko and Woźniak (2017) discovered the findings that less than $30 \%$ of the biggest corporations issue messages and information not only about their corporate social responsibility programmes and activities on their websites, while for about $66 \%$ of new employees - of new employees, such information would engage them to send their application to this potential corporation.

According to Plchová and Turáková (2016) and their research studies, it can be said that students also in China and in Slovakia feel interest in job description information about job position and working environment - $(80 \%$ of students from Slovakia and $76 \%$ of students from China). According to the results of the survey, primary information about the corporation, its vision, values and goals are particularly significant for the Slovak students $75 \%$ of respondents from Slovakia and $52 \%$ respondents from China). Compared to the website of corporation, students have the possibility to get on social networks references about the given corporation, ranking and comparison of different companies and assessment of the end users. For students from both countries are further important information about the work environment and possibilities for further training and career development in the corporations.

Researches showed that corporations are increasingly competing to attract highly qualified people in different specialized fields; therefore, those corporations that attract the best human resources will have a distinct edge in the marketplace (Maheshwari, Gunesh, Lodorfos and Konstantopoulou, 2017).

Heilmann, Saarenketo and Liikkanen (2013) highlight in their research survey, the major factors for employer branding strategy are better employer name and image, improved job satisfaction, more active and effective recruitment and improved job motivation.

Otken and Okan (2016) dealt with Generation Y in their research study. The results of the researches present that respondents were involved in the study want to work in (1) technology, (2) entertainment and (3) automotive sectors. The Generation Y respondents also want to work in Turkcell, Apple, Google, Microsoft, Vodafone, Mercedes and BMW. Also, they think that creativity and openness to innovation are the most significant attributes of today's employee.

According to Kissel and Büttgen (2015) and their researches, information collected from social media and self-congruity have no immediate impacts on perceived employer attractiveness and application intentions but are completely mediated by a strong company image.

\section{Conclusion}

The main objective of this contribution was to determine the factors influencing: (1) the job search and (2) job selection based on the gender of the respondents and the type of faculty in the employer branding context. The students of Generation Y introduced a research sample of respondents.

The research results discovered the finding that the mean perception of the factors influencing the job search and job selection in the employer branding context for females and males was as the same. This mean perception differed for one factor only: (1) other employee benefits. It means that this one factor showed differences in perception between women and men. 
And also, the mean perception of the factors influencing the job search and job selection in the employer branding context for Generation Y students of the FHS and FaME was as the same. This mean perception differed for five factors only: (1) certainty of employment, (2) permanent salary/wages, (3) good relationships in the workplace, (4) existence of corporate rules, (5) space for own realization. It means that these five factors showed differences in perception between Generation Y students of the FHS and FaME.

Information about potential employers was also investigated. The most frequent information about potential employers in the employer branding context was information about job position and working conditions. And then, these factors followed: (1) references and corporation rating (work atmosphere, career opportunities, and so on), (2) general information about corporation (core values, targets, vision, and so on), (3) information about internships or trainee programs for students.

A value and an originality of this article are based on discovery the factors influencing the job search and job selection in the employer branding context in Generation $\mathrm{Y}$ students and findings opinions on information about potential employers that is relevant, interesting and plays an important part for Generation $Y$ students.

This research has got certain limits - it is obvious that the number of respondents was not so large. The respondents were only: (1) people from Czech Republic, (2) people from Generation Y, (3) university students, (4) students of the FHS and FaME. Despite these weaknesses and limitations of this research, it is hoped for fact that the research has provided new, interesting and original information and findings in this research area.

This paper offers interesting and different questions for further research. One question is the discovery and discussion about factors influencing the job search and job selection people in Generation $\mathrm{Z}$ and Generation X in the employer branding context. The second question to be explored could be the decision of respondents to go to work to a certain corporation based on employer branding. And finally, a comparative research between people of Generation X, Y and Z should take place (in context their expectations, needs, opinions and employer branding).

\section{References}

Ambler, T. and Barrow, S. (1996), "The employer brand", The Journal of Brand Management, Vol. 04, No. 03, pp. 185-206.

App, S., Merk, J. and Büttgen, M. (2012), "Employer branding: Sustainable HRM as a competitive advantage in the market for high-quality employees", Management Revue, Vol. 23, No. 03, pp. 262-278.

Backhaus, K. B. and Tikoo, S. (2004), "Conceptualizing and researching employer branding", Career Development International, Vol. 09, No. 05, pp. 501-517.

Barrow, S. and Mosley, R. (2011), The employer brand: Bringing the best of brand management to people at work. Hoboken, NJ: John Wiley \& Sons.

Bednall, D., Valos, H., Adam, S. M. and McLeod, C. (2012), "Getting Generation Y to Attend: Friends, Interactivity and Half-time Entertainment", Sport Management Review, Vol. 15, No. 01, pp. 80-90. 
Berthon, P., Ewing, M. and Hah, L. L. (2005), "Captivating company: dimensions of attractiveness in employer branding", International Journal of Advertising, Vol. 24, No. 02, pp. 151-172.

Brymer, R. A., Molloy, J. C. and Gilbert, B. A. (2014), "Human capital pipelines competitive implications of repeated interorganizational hiring", Journal of Management, Vol. 40, No. 02, pp. 483-508.

Bursová, I. (2009), "Má smysl v této době budovat zaměstnavatelskou značku? A jak na to?", available at http://www.hrmanager.cz/files/hrforum0309.pdf, (accessed: February 28, 2018).

Cogin, J. (2012), “Are generational differences in work values fact or fiction? Multicountry evidence and implications", The International Journal of Human Resource Management, Vol. 23, No. 11, pp. 2268-2294.

Collins, C. J. and Kanar, A. M. (2013), "Employer brand equity and recruitment research", in: Cable, D. M. and Yu, K. Y. T., The Oxford Handbook of Recruitment. Oxford: Oxford University Press, pp. 284-297.

Collins, C. J. and Stevens, C. K. (2002), "The relationship between early recruitmentrelated activities and the application decisions of new labor-market entrants: a brand equity approach to recruitment", Journal of Applied Psychology, Vol. 87, No. 06, pp. 1121-1133.

Curus, C. (2008), "Invazia tinerilor născuţi în digital. România Liberă", available at http://www.romanialibera.ro/a123322/invazia-tinerilor-nascuti-indigital.html, (accessed: February 28, 2018).

Dabirian, A., Kietzmann, J. and Diba, H. (2017), “A great place to work!? Understanding crowdsourced employer branding", Business Horizons, Vol. 60, No. 02, pp. 197 205.

Davies, G. (2008), "Employer branding and its influence on managers", European Journal of Marketing, Vol. 42, No. 05/06, pp. 667-681.

Deaconu, A., Marinas, C. and Puia, R. (2008), “Assessment of the employees' performance - premise for the increase of the quality of the distribution services", Management \& Marketing. Challenges for the Knowledge Society, Vol. 03, No. 03, pp. 69-86. ISSN 2069-8887.

Drury, P. (2016), "Employer branding: Your not-so-secret weapon in the competition for young workers", Human Resource Management International Digest, Vol. 24, No. 03, pp. 29-31.

Edwards, M. R. and Edwards, T. (2013), "Employee responses to changing aspects of the employer brand following a multinational acquisition: a longitudinal study", Human Resource Management, Vol. 52, No. 01, pp. 27-54.

Franca, V. and Pahor, M. (2012), "The strength of the employer brand: influences and implications for recruiting", Journal of Marketing and Management, Vol. 03, No. 01, pp. 78-122.

Guthridge, M., Komm, A. B. and Lawson, E. (2008), "Making talent a strategic priority”, McKinsey Quarterly, Vol. 01, pp. 49-59.

Heilmann, P., Saarenketo, S., \& Liikkanen, K. (2013), “Employer branding in power industry", International Journal of Energy Sector Management, Vol. 07, No. 02, pp. 283-302. 
Horváthová, P., Bláha, J. a Čopíková, A. (2016), Řízení lidských zdrojů. Nové trendy. 1. vyd. Praha: Management Press. 428 s. ISBN 978-80-7261-430-1.

Chapman, D. S., Uggerslev, K. L., Carroll, S. A., Piasentin, K. A. and Jones, D. A. (2005), "Applicant attraction to organisations and job choice: a meta-analytic review of the correlates of recruiting outcomes", Journal of Applied Psychology, Vol. 90, No. 05, pp. 928-944.

Charbonnier-Voirin, A., Poujol, J. F. and Vignolles, A. (2017), "From value congruence to employer brand: Impact on organizational identification and word of mouth", Canadian Journal of Administrative Sciences, Vol. 34, No. 04, pp. 429-437.

Keller, K. L. (2013), Strategic Brand Management: Building, Measuring, and Managing Brand Equity. Harlow, Pearson Education.

King, C. and Grace, D. (2008), "Internal branding: exploring the employee's perspective", Journal of Brand Management, Vol. 15, No. 05, pp. 358-372.

Kissel, P. and Büttgen, M. (2015), "Using social media to communicate employer brand identity: The impact on corporate image and employer attractiveness", Journal of Brand Management, Vol. 22, No. 09, pp. 755-777.

Klapilová Krbová, P. (2016), “Generation Y Attitudes towards Shopping: A Comparison of the Czech Republic and Slovakia", Journal of Competitiveness, Vol. 08, No. 01, pp. 38-54.

Knight, R. (2014), "Managing people from 5 generations", Harvard Business Review, available at https://hbr.org/2014/09/managing-people-from-5-generations, (accessed: February 28, 2018).

Lane, P. (2016), "Human resources marketing and recruiting: essentials of employer branding", in: Zeuch, M., Handbook of Human Resources Management. Berlin: Springer, pp. 23-52.

Leekha Chhabra, N. and Sharma, S. (2014), "Employer branding: strategy for improving employer attractiveness", International Journal of Organizational Analysis, Vol. 22, No. 01, pp. 48-60.

Lievens, F. (2007), "Employer branding in the Belgian Army: the importance of instrumental and symbolic beliefs for potential applicants, actual applicants, and military employees", Human Resource Management, Vol. 46, No. 01, pp. 5169.

Lievens, F. and Slaughter, J. E. (2016), "Employer image and employer branding: what we know and what we need to know", Annual Review of Organizational Psychology and Organizational Behavior, Vol. 03, No. 01, pp. 407-440.

Maheshwari, V., Gunesh, P., Lodorfos, G. and Konstantopoulou, A. (2017), "Exploring HR practitioners' perspective on employer branding and its role in organisational attractiveness and talent management", International Journal of Organizational Analysis, Vol. 25, No. 05, pp. 742-761.

Mark, P. and Toelken, K. (2009), "Poisoned by a toxic brand: A worst case scenario of employer branding - A case study of a Fortune 100 technology firm", Organization Development Journal, Vol. 27, No. 04, pp. 21-29.

Martindale, N. (2010), “Think before you leap", Personnel Today, Vol. 01, pp. 18-46.

McDonnell, A. (2011), "Still fighting the "war for talent"? Bridging the science versus practice gap", Journal of Business and Psychology, Vol. 26, No. 02, pp. 169-173. 
Mitra Crişan, C. (2013), “Approaching Corporate Social Responsibility Trough Cross Sector Social Partnerships - Case Study of Bufab Romania", Management \& Marketing. Challenges for the Knowledge Society, Vol. 08, No. 04, pp. 623-636. ISSN 2069-8887.

Moroko, L. and Uncles, M. D. (2008), "Characteristics of successful employer brands", Journal of Brand Management, Vol. 16, No. 03, pp. 160-175.

Noble, M. S., Haytko, D. L. and Phillips, J. (2009), "What Drives College-age Generation Y consumers?”, Journal of Business Research, Vol. 62, No. 06, pp. 617-628.

Otken, A. B. and Okan, E. Y. (2016), "The Role of Social Media in Employer Branding”, Entrepreneurship, Business and Economics, Vol. 01, No. 03-01, pp. 245-260.

Peretti, J.-M. and Swalhi, A. (2007), “Définir et mesurer la fidélité organisationnelle”, Revue de Sciences de Gestion, Vol. 64, No. 01, pp. 277-290.

Plchová, J. and Turáková, A. (2016), "Employer branding of the companies and its impact on university students - trends research in Slovakia and China", Marketing Identity, Vol. 04, No. 01/02, pp. 247-256.

Popescu, A. I. (2012), "Branding Cities as Educational Centres. The Role of Higher Education Institutions", Management \& Marketing. Challenges for the Knowledge Society, Vol. 07, No. 03, pp. 493-512. ISSN 2069-8887.

Porvazník, J., Ljudvigová, I. and Vydrová, J. (2017), “The importance of holistic managerial competence and social maturity in human crisis", Polish Journal of Management Studies, Vol. 15, No. 01, pp. 163-173.

Racolţa-Paina, N.-D. and Luca, T. A. (2011), "Nowadays Online Consumers' Rights and Interests. Case Study - The Romanian Educated Online Young Consumer", Management \& Marketing. Challenges for the Knowledge Society, Vol. 06, No. 02, pp. 255-272. ISSN 2069-8887.

Reis, G. G. and Braga, B. M. (2016), "Employer attractiveness from a generational perspective: Implications for employer branding", Revista de Administração, São Paulo, Vol. 51, No. 01, pp. 103-116.

Saleem, F. Z. and Iglesias, 0. (2016), "Mapping the domain of the fragmented field of internal branding", Journal of Product \& Brand Management, Vol. 25, No. 01, pp. 43-57.

Shaikh Ibrahim, N. B. (2016), “Employer branding: an Islamic perspective”, The South East Asian Journal of Management, Vol. 10, No. 02, pp. 108-120.

Shaw, S. and Fairhurst, D. (2008), "Engaging a New Generation of Graduates", Education and Training, Vol. 50, No. 05, pp. 366-378.

Shen Kian, T., Wan Yusoff, W. F. and Rajah, S. (2013), "Relationship between Motivations and Citizenship Performance among Generation X and Generation Y", International Journal of Academic Research in Business and Social Sciences, Vol. 03, No. 11, pp. 53-68.

Soulez, S. and Guillot-Soulez, C. (2011), "Marketing de recrutement et segmentation générationnelle: regard critique à partir d'un sous segment de la génération Y", Recherche et Applications en Marketing, Vol. 26, No. 01, pp. 39-57.

Srivastava, P. and Bhatnagar, J. (2010), "Employer brand for talent acquisition: an exploration towards its measurement", Vision, Vol. 14, No. 01/02, pp. 25-34.

Stuss, M. and Herdan, A. (2017), "External employer branding tools used for attracting graduates by energy companies listed at Warsaw stock exchange", in: 
Proceedings of 8th Economics \& Finance Conferences, London: International Institute of Social and Economic Sciences. pp 200-213.

Urbancová, H. and Hudáková, H. (2017), "Benefits of Employer Brand and the Supporting Trends", Economics and Sociology, Vol. 10, No. 04, pp. 41-50.

Urbancová, H., Richter, P., Kučírková, L. and Jarkovská, M. (2017), “Employer branding in the agricultural sector: making a company attractive for the potential employees", Agricultural Economics (Zemědělská ekonomika), Vol. 63, No. 05, pp. 217-227.

Vendolská, I. and Kačerová, E. (2016), "Flexible Graduate is Successful Graduate. Key Factors of Successful Job Interview, Results of a Comparative Analysis", Journal of Competitiveness, Vol. 08, No. 02, pp. 87-102.

Wan Yusoff, W. F. and Shen Kian, T. (2013), "Generation Differences in Work Motivation: From Developing Country Perspective", International Journal of Economy, Management and Social Sciences, Vol. 02, No. 04, pp. 97-103.

Wołodźko, K. and Woźniak, J. (2017), "The Use by Large Polish Organizations of Information about CSR Activities in e-Recruitment", Economics and Sociology, Vol. 10, No. 02, pp. 47-60.

Xie, CH., Bagozzi, R. P. and Meland, K. V. (2015), "The impact of reputation and identity congruence on employer brand attractiveness", Marketing Intelligence \& Planning, Vol. 33, No. 02, pp. 124-146.

Zemke, R., Raines, C. and Filipczak, B. (2000), Generations at Work: Managing the Clash of Veterans, Boomers, Xers, and Nexters in Your Workplace. 1st ed. New York: Amacom. 288 p. ISBN 978-0-8144-0480-5. 